\title{
ДОСЛІДЖЕННЯ ОСОБЛИВОСТЕЙ ОСОБИСТІСНИХ ЦІННОСТЕЙ МОЛОДШИХ ШКОЛЯРІВ
}

Стаття присвячена дослідженню достовірних відмінностей у рівні розвитку показників ияіннісного компоненту соціально-психологічної компетентності школярів у сфері нормовідповідності власної поведінки залежно від їхньої статі, віку, сочіально-економічного

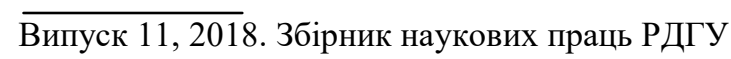


статусу сім'ї та соціометричного статусу в класі. Емпіричними показниками иіннісного компоненту соціально-психологічної компетентності молодших иколярів у сфері нормовідповідності власної поведінки стали психологічні шкали: чесність, вихованість, терпимість, широта поглядів, відповідальність, незалежність, підприємливість, освіченість, тверда воля, самоконтроль, чуйність, ефективність у справах, жсттєрадісність, багатство, старанність, сміливість у відстоюванні поглядів.

Ключові слова: иінності, нормовідповідність поведінки, стать, вік, соціально-економічний статус, соиіометричний статус, молодший школяр, відповідальність, незалежність, освіченість, тверда воля, багатство.

Статья посвящена исследованию различий уровня развития показателей ценносного составляющего социально-психологической компетентности школьников в сфере соответствия собственного поведения нравственным нормам в зависимости от их пола, возраста, социальноекономического статуса семьи и социометрического статуса в классе. Эмпирическими показателями иенносного составляющего социально-психологической компетентности младших икольников в сфере нормосоответственности собственного поведения выступают психологические шкаль: честность, воспитанность, терпимость, иирота взглядов, ответственность, независимость, предпринимательность, образованность, твердая воля, самообладание, отзывчивость, ефективность в делах, жизнерадостность, богатство, прилежность, смелость в отстаивании взглядов.

Ключевые слова: иенности, нормосоответствие поведения, пол, возраст, социальноекономический статус, младший школьник, ответственность, независимость, образованность, твердая воля, богатство.

Постановка проблеми. Підсумком розвитку особистості молодшого школяра $\epsilon$ формування цінностей як компоненту усвідомленої та узагальненої самооцінки, стриманість у прояві почуттів, усвідомлення вольових дій та формування вольових якостей. Проблема залежності особистісних цінностей молодшого школяра від віку, статі, соціально-економічного статусу сім’і та соціометричного статусу в класі є складовою проблеми морального розитку дитини та, зокрема, нормовідповідності її поведінки.

Аналіз останніх досліджень і публікацій. Важливим критерієм ефективності та якості процесу виховання $є$ нормовідповідність поведінки школярів - наявність у них високих моральних якостей і цінностей. Одним із суттєвих показників рівня вихованості школяра $\epsilon$ формування його особистісних цінностей. І. Бех, М. Борищевський, Л. Божович визначили суть поняття „цінності” як утворення, в основі яких лежать почуття людей, що спрямовані на ідеал. Цінність - це властивість самих речей, які відповідні певним цілям, намірам, планам $[1,2,3]$. Однак проблемі залежності особистісних цінностей молодшого школяра від різних змінних (зокрема, від віку, статі, соціальноекономічного статусу сім'ї та соціометричного статусу в класі) не приділено достатньої уваги.

Вивчення проблеми ціннісних орієнтацій займає важливе місце в сучасній соціальній психології. Для з'ясування сутності явища психологи вживають такі поняття як “ціннісні орієнтації”, “настанови ", “схильності”. Також цінності можна визначити як елементи моральної поведінки. На думку С.М. Лупінович, ці поняття поєднуються з цілями, прагненнями та життєвими ідеалами, які існують у “груповій” свідомості у формі певних моральних норм, з життєвим досвідом, накопиченим особистістю в іiі індивідуальному розвитку[6]. У психології цінності називають "значущістю", “життєвою позицією” (Л. Божович), “значенням” і “особистісним змістом” (О.Леонтьєв), “психологічними відношеннями” (В.Мясищев)[7]. Вони є складовими мотивації людини. Система засвоєних індивідом знань, які зумовлені його потребами, інтересами та зафіксовані в його настановах, складається в ціннісні орієнтації особистості, конкретне ставлення до цінностей життя [9].

Формулювання цілей статті. Метою нашого повідомлення $\epsilon$ дослідження питання відмінностей у рівні розвитку показників ціннісного компоненту соціально-психологічної компетентності школярів у сфері нормовідповідності власної поведінки залежно від їхньої статі, віку, соціально-економічного статусу сім'ї та соціометричного статусу в класі. Складність проблеми зумовлена неоднозначністю зв'язків, що існують між досліджуваними процесами та величезною практичною значущістю розкриття певних закономірностей. Згідно із сформульованою метою нашими завданнями є: характеристика поняття «цінності» як компоненту нормовідповідної поведінки молодших школярів, аналіз останніх публікацій із проблематики нашої роботи та здійснення емпіричного дослідження соціально-психологічної компетентності школярів у сфері 
нормовідповідності власної поведінки залежно від їхньої статі, віку, соціально-економічного статусу сім'ї та соціометричного статусу в класі.

Виклад основного матеріалу дослідження. Вихованість, терпимість, широта поглядів, відповідальність, незалежність, освіченість, тверда воля, самоконтроль, ефективність у справах, старанність, сміливість у відстоюванні поглядів - це основні якості, якими необхідно оволодіти школяреві. Мова йде про показники ціннісного компоненту соціально-психологічної компетентності школярів у сфері нормовідповідності власної поведінки. Розглянемо залежність даних якостей молодших школярів від статі, віку, соціально-економічного статусу сім'ї та соціометричного статусу в класі .

Дослідження проводилось на базі Рівненської гімназії «Гармонія», Рівненської класичної гімназії «Престиж» (м. Рівне), Луцьких загальноосвітніх шкіл I-III ступенів №5 і №8 (м. Луцьк) та Тернопільської загальноосвітньої школи I-III ступенів №19 (м. Тернопіль). Досліджуваними стали учні перших-четвертих класів у кількості 189 осіб. Дослідницький контингент було диференційовано за критеріями статі (97 осіб жіночої статі та 92 особи чоловічої статі) та віку (6-7-ми річного віку - 50 осіб, 8-ми річного віку - 47 осіб, 9-ти річного віку - 46 осіб, 10-ти річного віку - 46 осіб).

Уході дослідження було здійснено порівняльний аналіз рівня розвитку показників ціннісного компоненту соціально-психологічної компетентності молодших школярів у сфері нормовідповідності власної поведінки. Групуючими змінними такого порівняльного аналізу було визначено показники їх статі, віку, соціально-економічного статусу сім'ї та соціометричного статусу в класі. Вимірювання рівня розвитку показників ціннісного компоненту соціально-психологічної компетентності молодших школярів у сфері нормовідповідності власної поведінки було здійснено за допомогою методики діагностики особистісних цінностей А. Журавльова, Н. Журавльової. Емпіричними показниками ціннісного компоненту соціально-психологічної компетентності молодших школярів у сфері нормовідповідності власної поведінки стали психологічні шкали: чесність, вихованість, терпимість, широта поглядів, відповідальність, незалежність, підприємливість, освіченість, тверда воля, самоконтроль, чуйність, ефективність у справах, життєрадісність, багатство, старанність, сміливість у відстоюванні поглядів. Показники соціометричного статусу в класі визначались в ході вивчення міжособистісних стосунків молодших школярів за допомогою соціометричної методики [5], а показники економічного статусу їх сім’ї - на основі інформації, наданої батьками та адміністрацією навчального закладу.

3 метою визначення достовірних відмінностей у рівні розвитку показників ціннісного компоненту соціально-психологічної компетентності школярів у сфері нормовідповідності власної поведінки залежно від їх статі було використано метод порівняння середніх значень (Compare Means) та непараметричний критерій відмінностей для незалежних вибірок Манна-Вітні (Mann-Whitney Test) [4]. Статистично значимий характер відмінностей у рівні розвитку показників ціннісного компоненту соціально-психологічної компетентності школярів у сфері нормовідповідності власної поведінки залежно від їх віку, соціально-економічного статусу сім'ї і соціометричного статусу в класі було використано непараметричний метод відмінностей для направлених (впорядкованих) альтернатив Джонкхієра-Терпстра (Jonckheere-Terpstra Test) [4]. Перевагою даного статистичного методу є те, що він дозволяє не лише порівнювати вибірки випробуваних між собою на предмет визначення достовірних відмінностей між вимірюваними ознаками, але і виявляти в отриманих результатах певні тенденції, або тренди, які є наслідком дії якого-небудь впорядкованого за своїми градаціями фактора. Власне такими факторами в нашому дослідженні виступають показники віку молодших школярів, соціально-економічного статусу їх сім'ї та соціометричного статусу в класі. Статистичний аналіз даних було здійснено за допомогою комп'ютерного пакету статистичних програм SPSS 17.0.

Порівняння середніх значень рангів показників випробуваних, виміряних за допомогою методики діагностики особистісних цінностей А. Журавльова, Н. Журавльової, дозволило виявити ряд важливих тенденцій. Перейдемо до їх змістової інтерпретації. Залежно від статі середні значення рангів особистісних цінностей молодших школярів розподілилися наступним чином (див. табл. 1). Порівняння означених характеристик в групах досліджуваних різної статі дозволяє стверджувати про певні відмінності у рівні їх вираженості. Проте з міркувань коректності подальшої інтерпретації виявлених тенденцій залишимо поза увагою детального аналізу ті відмінності у середніх значеннях рангів особистісних цінностей випробуваних, які не мають достовірного характеру. Перевірка виявлених тенденцій на предмет їх статистично значимого характеру не підтвердила достовірного зв'язку статі 3 жодною з порівнюваних особистісних характеристик досліджуваних $(p>0,05)$. Власне такі результати можуть свідчити про відсутність достовірних відмінностей між молодшими школярами різної статі за рівнем розвитку їх ціннісного компоненту соціально-психологічної компетентності у сфері нормовідповідності власної поведінки. Найбільш ймовірним поясненням Випуск 11, 2018. Збірник наукових праць РДГУ 
виявленого факту, на наш погляд, є те, що молодші школярі мають невеликий життєвий досвід і в силу свого віку вони недостатньо інтегровані в соціум. У традиційній моделі навчання відбуваються останнім часом значні зміни, пов'язані із розвитком нових уявлень про можливості освіти й виховання молодших школярів, із науково-технічним прогресом, що вимагає від учнів навіть наймолодшої ланки вміння переносити знання в нову ситуацію, гнучкості та оригінальності мислення, проявляти творчу ініціативу, розвивати здібності, планувати навчальний процес, контролювати та оцінювати хід і результати навчання. А це означає, що обов'язковими для учнів $\epsilon$ певні цінності (див. табл.1) незалежно від статевої приналежності.

Таблиия 1

Відмінності середніх значень рангів особистісних цінностей досліджуваних залежно від їх статі

\begin{tabular}{|c|c|c|c|}
\hline \multirow[t]{2}{*}{ Особистісні цінності } & \multicolumn{2}{|c|}{$\begin{array}{c}\text { Середні значення рангів особистісних цінностей у } \\
\text { представників діночої та чоловічої статі }\end{array}$} & \multirow[t]{2}{*}{$\mathrm{P}$} \\
\hline & дівчата & хлопці & \\
\hline Чесність & 3,74 & 3,69 & 0,874 \\
\hline Вихованість & 5,21 & 5,18 & 0,947 \\
\hline Терпимість & 7,72 & 7,67 & 0,928 \\
\hline Широта поглядів & 10,63 & 10,69 & 0,965 \\
\hline Освіченість & 7,96 & 8,03 & 0,894 \\
\hline Відповідальність & 7,84 & 7,76 & 0,874 \\
\hline Старанність & 6,57 & 6,10 & 0,632 \\
\hline Незалежність & 10,03 & 10,12 & 0,917 \\
\hline Підприємливість & 10,69 & 10,81 & 0,883 \\
\hline Тверда воля & 9,94 & 10,02 & 0,871 \\
\hline Самоконтроль & 8,79 & 8,68 & 0,849 \\
\hline Чуйність & 8,85 & 8,63 & 0,773 \\
\hline Життєрадісність & 9,23 & 9,21 & 0,970 \\
\hline Ефективність у справах & 10,09 & 9,96 & 0,854 \\
\hline Багатство & 9,69 & 9,77 & 0,826 \\
\hline $\begin{array}{l}\text { Сміливість у відстоюванні } \\
\text { поглядів }\end{array}$ & 9,16 & 8,90 & 0,769 \\
\hline
\end{tabular}

Отже, продукт, створений молодшим школярем (незалежно від його статі), який володіє вище перерахованими характеристиками, набуває суб'єктивної новизни та особистісної значимості, а продукт діяльності має суспільно значиму цінність. Тобто мова йде про цінність особистості в цілому.

Перейдемо до змістовного аналізу результатів порівняння середніх значень рангів особистісних цінностей молодших школярів за критерієм віку. Залежно від віку середні значення рангів особистісних цінностей випробуваних розподілилися наступним чином (див. табл. 2). Узагальнення табличних даних дозволило в даному випадку виявити різнонаправлену динаміку вираженості особистісних цінностей молодших школярів. Зокрема, тренд до зростання 3 першого по четвертий клас продемонстрували такі цінності молодших школярів, як «багатство» $\mathrm{i}$ «відповідальність». Натомість динаміку зниження значень середніх рангів продемонстрували цінності «освіченість», «незалежність» і «тверда воля», що свідчить про підвищення 3 віком їх особистої значимості для досліджуваних. Перевірка виявлених тенденцій у розподілі цінностей досліджуваних на предмет їх статистично значимого характеру дозволила підтвердити достовірний зв'язок між віком та означеними особистісними цінностями - «багатство» (р<0,01), «освіченість» $(\mathrm{p}<0,05)$, «незалежність» $(\mathrm{p}<0,05)$, «відповідальність» $(\mathrm{p}<0,05)$, «тверда воля» $(\mathrm{p}<0,05)$. Проведемо змістову інтерпретацію виявлених закономірностей.

3 психологічної точки зору причинами зниження цінності багатства із збільшенням віку в молодшому шкільному віці $є$ зміна пріоритетів. Якщо діти 6-7 років вважали, що наявність фінансів впливає на їхній настрій (є гроші - йдемо купувати продукти й подарунки, немає - живемо погано), то 10-11- річні школярі вже вміють зекономити кишенькові гроші, проявити терпіння та тверду волю у відповідних ситуаціях. До кінця молодшого шкільного віку у дітей формується уявлення про джерело отримання прибутку. Зниження цінності відповідальності можна пояснити віковими особливостями. Оскільки для молодших школярів авторитетною фігурою $є$ вчитель, то вони відчувають себе відповідальними перед ним. Наближаючись же до підліткового періоду (у нашому 
випадку це кінець молодшого шкільного віку), школяр все більше орієнтується на коло однолітків, тим самим зменшуючи міру відповідальності перед завданнями, поставленими вчителем. Що стосується таких якостей як освіченість, незалежність та тверда воля, то їхня цінність підвищується 3 віком (у міру дорослішання та пов’язаних із ним вікових особливостей школяра).

Таблиия 2

Відмінності середніх значень рангів особистісних цінностей досліджуваних залежно від їх віку

\begin{tabular}{|l|c|c|c|c|c|}
\hline \multirow{2}{*}{ Особистісні цінності } & \multicolumn{2}{|c|}{ Середні значення рангів особистісних цінностей } & \multirow{2}{*}{ Р } \\
\cline { 2 - 5 } & $\begin{array}{c}\text { перший } \\
\text { клас }\end{array}$ & $\begin{array}{c}\text { другий } \\
\text { клас }\end{array}$ & $\begin{array}{c}\text { третій } \\
\text { клас }\end{array}$ & $\begin{array}{c}\text { четвертий } \\
\text { клас }\end{array}$ & \\
\hline Чесність & 3,72 & 4,45 & 3,92 & 2,77 & 0,331 \\
\hline Вихованість & 5,94 & 5,87 & 4,28 & 5,42 & 0,457 \\
\hline Терпимість & 7,11 & 7,19 & 8,28 & 7,23 & 0,856 \\
\hline Широта поглядів & 11,0 & 10,71 & 10,12 & 10,55 & 0,689 \\
\hline Освіченість & 9,64 & 6,84 & 6,96 & 7,42 & 0,030 \\
\hline Відповідальність & 7,06 & 6,74 & 8,96 & 8,74 & 0,038 \\
\hline Старанність & 6,22 & 6,19 & 7,96 & 6,71 & 0,224 \\
\hline Незалежність & 11,17 & 10,97 & 10,08 & 8,87 & 0,032 \\
\hline Підприємливість & 10,61 & 10,16 & 11,40 & 11,23 & 0,360 \\
\hline Тверда воля & 10,58 & 10,52 & 9,48 & 9,29 & 0,038 \\
\hline Самоконтроль & 8,56 & 9,55 & 7,96 & 8,23 & 0,516 \\
\hline Чуйність & 8,58 & 9,26 & 9,60 & 8,13 & 0,863 \\
\hline Життерадісність & 8,75 & 8,45 & 9,00 & 9,61 & 0,418 \\
\hline Ефективність у справах & 10,19 & 9,26 & 9,52 & 10,77 & 0,683 \\
\hline Багатство & 7,69 & 10,77 & 8,00 & 11,97 & 0,008 \\
\hline Сміливість у відстоюванні & 9,06 & 9,16 & 10,48 & 11,16 & 0,555 \\
\hline поглядів & & & & & \\
\hline
\end{tabular}

Перейдемо до змістовного аналізу результатів порівняння середніх значень рангів особистісних цінностей молодших школярів за критерієм соціально-економічного статусу їх сім'ї (див. табл. 3).

\section{Відмінності середніх значень рангів особистісних цінностей досліджуваних залежно від соціально-економічного статусу їх сім'ї}

\begin{tabular}{|c|c|c|c|c|}
\hline \multirow[t]{2}{*}{ Особистісні цінності } & \multicolumn{3}{|c|}{\begin{tabular}{|c|} 
Середні значення рангів \\
особистісних цінностей за умови різного соціально- \\
економічного статусу сім'ї
\end{tabular}} & \multirow[t]{2}{*}{$\mathrm{P}$} \\
\hline & низький & середній & високий & \\
\hline Чесність & 4,14 & 3,68 & 3,50 & 0,435 \\
\hline Вихованість & 6,43 & 5,39 & 5,00 & 0,216 \\
\hline Терпимість & 8,93 & 7,22 & 7,13 & 0,325 \\
\hline Широта поглядів & 9,29 & 10,88 & 10,38 & 0,554 \\
\hline Освіченість & 7,36 & 8,09 & 6,75 & 0,576 \\
\hline Відповідальність & 6,86 & 7,53 & 10,13 & 0,037 \\
\hline Старанність & 7,64 & 6,46 & 7,19 & 0,734 \\
\hline Незалежність & 9,86 & 10,38 & 10,38 & 0,833 \\
\hline Підприємливість & 9,93 & 10,89 & 11,13 & 0,299 \\
\hline Тверда воля & 10,79 & 9,98 & 9,56 & 0,309 \\
\hline Самоконтроль & 9,07 & 8,68 & 7,75 & 0,355 \\
\hline Чуйність & 9,21 & 8,72 & 9,25 & 0,886 \\
\hline Життсрадісність & 7,86 & 9,10 & 9,00 & 0,557 \\
\hline Ефективність у справах & 9,71 & 10,13 & 9,25 & 0,861 \\
\hline Багатство & 8,14 & 9,77 & 9,94 & 0,370 \\
\hline $\begin{array}{l}\text { Сміливість у відстоюванні } \\
\text { поглядів }\end{array}$ & 10,79 & 9,81 & 9,69 & 0,545 \\
\hline
\end{tabular}


Враховуючи принцип приписування рангів, можна стверджувати про достовірний, а відтак закономірний характер зменшення у молодших школярів із сімей з високим соціально-економічним статусом особистісної значимості такої цінності, як «відповідальність». Даному факту є логічне пояснення. Відповідальність не виникає сама по собі, а зароджується, розвивається і виховується, закріплюється тими суспільними умовами, у яких живе молодший школяр. Недостовірний та суперечливий характер інформації, негативні приклади дійсності сприяють формуванню в учнів помилкових уявлень про етичні норми, припустиме і неприпустиме в їхній поведінці [8]. Безвідповідальність дітей часто формують їхні батьки. Формують по-різному. Іноді опікуючи, перевиховуючи та оберігаючи від труднощів і життєвих негараздів. Іноді караючи і пригнічуючи, в результаті чого у дитини виникає байдужість і озлобленість по відношенню до дорослих і їх дорослого світу. Але найчастіше формують просто проживаючи в присутності дітей звичайним дорослим безвідповідальним життям (частіше це спостерігається у сім'ях із високим соціальноекономічним статусом).

Ще однією групуючою змінною, на основі якої здійснювався порівняльний аналіз емпіричних даних досліджуваних, став їх соціометричний статус в класі. Залежно від соціометричного статусу в класі середні значення рангів особистісних цінностей молодших школярів розподілилися наступним чином (див. табл. 4).

Таблиия 4

Відмінності середніх значень рангів особистісних цінностей досліджуваних залежно від їх соціометричного статусу в класі

\begin{tabular}{|l|c|c|c|c|c|}
\hline \multirow{2}{*}{ Особистісні цінності } & \multicolumn{2}{|c|}{ Середні значення рангів особистісних цінностей } & \multirow{2}{*}{ Р } \\
\cline { 2 - 5 } & ізольовані & прийняті & бажані & зірки & \\
\hline Чесність & 3,52 & 4,12 & 3,34 & 3,47 & 0,832 \\
\hline Вихованість & 5,48 & 5,53 & 5,66 & 4,82 & 0,599 \\
\hline Терпимість & 8,92 & 6,92 & 6,69 & 7,88 & 0,410 \\
\hline Широта поглядів & 10,56 & 10,49 & 11,09 & 10,29 & 0,839 \\
\hline Освіченість & 8,64 & 7,59 & 7,91 & 7,18 & 0,299 \\
\hline Відповідальність & 7,56 & 7,96 & 7,16 & 8,82 & 0,789 \\
\hline Старанність & 7,24 & 6,90 & 6,53 & 5,59 & 0,226 \\
\hline Незалежність & 11,04 & 9,92 & 10,53 & 10,00 & 0,709 \\
\hline Підприємливість & 10,72 & 10,59 & 10,91 & 11,41 & 0,449 \\
\hline Тверда воля & 10,40 & 9,55 & 10,97 & 9,00 & 0,865 \\
\hline Самоконтроль & 9,28 & 8,73 & 7,91 & 8,53 & 0,312 \\
\hline Чуйність & 8,44 & 9,53 & 8,66 & 7,82 & 0,517 \\
\hline Життерадісність & 7,36 & 9,18 & 9,00 & 10,47 & 0,109 \\
\hline Ефективність у справах & 10,32 & 9,53 & 10,31 & 10,06 & 0,916 \\
\hline Багатство & 7,36 & 10,37 & 9,72 & 10,53 & 0,048 \\
\hline Сміливість у відстоюванні & 9,16 & 9,29 & 9,31 & 13,88 & 0,381 \\
\hline поглядів & & & & & \multirow{2}{*}{10} \\
\hline
\end{tabular}

Згідно з табличними даними, маємо виражений тренд до зростання у молодших школярів, які мають високий соціометричний статус в класі («зірки»), середніх значень рангів таких особистісних цінностей, як «відповідальність», «підприємливість», «життєрадісність», «багатство» та «сміливість у відстоюванні поглядів». Перевірка виявлених тенденцій у розподілі особистісних цінностей школярів на предмет їх статистично значимого характеру підтвердила достовірний зв'язок між їх соціометричним статусом в класі і такою особистісною цінністю, як «багатство» $(\mathrm{p}<0,05)$. Це означає, що у найбільш статусних молодших школярів («зірок») цінність «багатство», враховуючи принцип приписування рангів, демонструє найменшу особистісну значимість. Щоб пояснити дану закономірність, розглянемо, які психологічні і соціальні фактори впливають на соціометричний статус суб'єкта в групі. Високий статус людини в групі обумовлений в першу чергу такими особливостями: зовнішня привабливість людини; успішність у груповій діяльності; достатній рівень інтелектуального розвитку; деякі особливості темпераменту (комунікабельність, низька тривожність, стабільність нервової системи); успішність в тих видах позагрупової діяльності, які значимі для більшості; наявність тих якостей особистості, які цінуються в даній групі [5].

Соціометричний статус визначається почуттями, які учасники взаємодії відчувають по відношенню один до одного. Причиною низького статусу може бути невміння спілкуватися 3 однолітками чи навіть неохайний зовнішній вигляд, але аж ніяк не матеріальний стан сім'ї учня. 
Висновки 3 даного дослідження і перспективи подальших розвідок у даному напрямку. Значущість емпіричного дослідження проблеми залежності особистісних цінностей молодшого школяра від віку, статі, соціально-економічного статусу сім’ї та соціометричного статусу в класі, що $\epsilon$ складовою проблеми морального розитку дитини та, зокрема, нормовідповідності іiі поведінки, складно переоцінити. Це зумовлено фундаментальністю загальної проблеми морального розвитку молодших школярів, тому вважаємо за доцільне продовжувати дослідження в даному напрямку і, зокрема, плануємо в подальших доробках описати та експериментально обгрунтувати нормовідповідну поведінку як моральну поведінку, використовуючи для цього ієрархічну теорію морального розвитку Л. Кольберга.

\section{Список використаних джерел}

1. Бех И. Д. Младший школьник в воспитательном пространстве межличностных взаимоотношений / И. Д. Бех // Начальная школа. - 2000. - № 5. - С. 1-3.

2. Божович Л. И. Личность и ее формирование в детском возрасте / Л. И. Божович. - СПб. : Питер, 2008. - 400 с.

3. Психологія самоактивності учнів у виховному процесі : навч.-метод. посіб. / М. Й. Борищевський, С. Т. Музичук, В. В. Антонечко та ін. ; Ін-т змісту і методів навчання; Ін-т психології ім. Г. С. Костюка АПН України. - Київ, 1999. - 190 с.

4. Бююль A. SPSS: искусство обработки информации: анализ статистических данных и восстановление скрытых закономерностей : пер. с нем. / А. Бююль, П. Цёфель. - СПб. : ДиаСофтЮГ, 2002. -608 c.

5. Коломінський Я. Л. Психологія взаємин у малих групах / Я. Л. Коломінський. - Мінск : Тетра Сістемс, 2000. - 432 с.

6. Лупінович С. М. Формування ціннісного ставлення до навчання в учнів молодших класів школи - комплексу естетичного виховання : дис. ... канд. пед. наук : 13.00 .07 / С. М. Лупінович ; Терноп. нац. пед. ун-т ім. В. Гнатюка. - Тернопіль, 2006. - 220 с.

7. Павелків Р. В. Молодший школяр у моральному вимірі міжособистісних відносин Р. В. Павелків // Оновлення змісту, форм та методів навчання і виховання в закладах освіти: зб. наук. пр. : наук. зап. Рівнен. держ. гуманіт. ун-ту. - Рівне, 2003. - Вип. 26. - С. 6-10.

8. Селуянова М. В. Почуття відповідальності дітей молодшого шкільного віку / М. В. Селуянова // Збірник наукових праць [Херсонського державного університету]. Педагогічні науки. - 2015. - Вип. 67. - С. 207-213.

9. Струманський В. П. Виховна робота в національній школі / В. П. Струманський. - Київ : I3MH, 1997. - $184 \mathrm{c}$.

1.Bekh Y. D. Mladshyi shkolnyk $\mathrm{v}$ vospytatelnom prostranstve mezhlychnostnukh vzaymootnoshenyi / Y. D. Bekh // Nachal'naya shkola. - 2000. - № 5. - S. 1-3.

2. Bozhovych L. Y. Lychnost y ee formyrovanye v detskom vozraste / L. Y. Bozhovych. $-\mathrm{SPb}$ : Pyter, 2008. $-400 \mathrm{~s}$.

3. Psykholohiia samoaktyvnosti uchniv u vykhovnomu protsesi : navch.-metod. posib. / M. Y. Boryshchevskyi, S. T. Muzychuk, V. V. Antonechko ta in. ; In-t zmistu i metodiv navchannia; In-t psykholohii im. H. S. Kostiuka APN Ukrainy - Київ, 1999. - 190 s.

4. Biuiul A. SPSS: yskusstvo obrabotky ynformatsyy: analyz statystycheskykh dannыkh y vosstanovlenye skrыtыkh zakonomernostei : per. s nem. / A. Biuiul, P. Tsëfel. - SPb. : DyaSoftluH, 2002. $608 \mathrm{~s}$.

5. Kolominskyi Ya. L. Psykholohiia vzaiemyn u malykh hrupakh / Ia. L. Kolominskyi. -Mynsk : Tetra Sistems, 2000. - 432 c.

6. Lupinovych S. M. Formuvannia tsinnisnoho stavlennia do navchannia v uchniv molodshykh klasiv shkoly - kompleksu estetychnoho vykhovannia : dys. ... kand. ped. nauk : 13.00.07 / S. M. Lupinovych ; Ternop. nats. ped. un-t im. V. Hnatiuka. - Ternopyl, 2006. $-220 \mathrm{~s}$.

7. Pavelkiv R.V. Molodshyi shkoliar u moralnomu vymiri mizhosobystisnykh vidnosyn / R. V. Pavelkiv // Onovlennia zmistu, form ta metodiv navchannia i vykhovannia v zakladakh osvity : zb. nauk. pr. : nauk. zap. Rivnen. derzh. humanit. un-tu. - Rivne, 2003. - Vyp. 26. - S. 6-10.

8. Seluianova M. V. Pochuttia vidpovidalnosti ditei molodshoho shkilnoho viku / M. V. Seluianova // Zbirnyk naukovykh prats [Khersonskoho derzhavnoho universytetu]. Pedahohichni nauky. - 2015. - Vyp. 67. - S. 207-213. 
9. Strumanskyi V. P. Vykhovna robota v natsionalnii shkoli / V. P. Strumanskyi. - Kyyv : IZMN, 1997. $-184 \mathrm{~s}$.

Khomych I. S. CHARACTERISTICS STUDY OF JUNIOR SCHOOL STUDENTS' PERSONAL VALUES.

The study is concerned with authoritative differences at the level of value constituent indicators development of students' social and psychological competence in their appropriateness for the own behavior standards depending on their gender, age, family social and economic position and sociometric position in a class. The author identifies empirical indicators of value constituent for students' social and psychological competence in their appropriateness for the own behavior standards. Such psychological rates as honesty, politeness, tolerance, breadth of view, responsibility, independence, flexibility, literacy, cast-iron will, selfcontrol, kind heartedness, activity effectiveness, joy of life, wealth, carefulness, braveness in viewpoints proving have been presented as empirical indicators.

The results indicate the absence of the authoritative differences between junior school students of different gender according to the level of their value constituent development of social and psychological competence in their appropriateness to the own behavior standards. The study demonstrates the decreasing of wealth value with age increasing for junior school students and personal significance decreasing of such value as responsibility for junior school students from families with high social and economic position.

The research has confirmed the fact that the wealth value demonstrates the least personal significance for the highest-positioned junior school students (the stars).

Key words: values, appropriateness to behavior standards, gender, age, social and economic position, sociometric position, junior school pupil, responsibility, independence, literacy, cast-iron will, wealth. 